Publisher homepage: www.universepg.com, ISSN: 2707-4641 (Online) \& 2707-4633 (Print)

https://doi.org/10.34104/ijma.022.01011

International Journal of Management and Accounting Journal homepage: www.universepg.com/journal/ijma

\title{
CAMEL-Based Performance of a Foreign Bank in Bangladesh: A Study on Commercial Bank of Ceylon
}

\author{
Stella Scholastica Crowley ${ }^{1,2 *}$, Mohammad Raton Sikder ${ }^{3}$, and Ajoy Dhar ${ }^{4}$ \\ ${ }^{1}$ Dept. of Business, BRAC University, Dhaka, Bangladesh; ${ }^{2}$ Dept. of International Trade, Commercial Bank of Ceylon \\ PLC- Bangladesh Operations, Dhaka, Bangladesh; ${ }^{3}$ Business School, ISCTE-IUL, Lisbon, Portugal; and ${ }^{4}$ Business \\ School, Yangzhou University, Jiangsu, China. \\ *Correspondence: stella.scholastica.crowley@g.bracu.ac.bd (Stella Scholastica Crowley, Department of Business, BRAC \\ University, Dhaka, Bangladesh).
}

\section{ABSTRACT}

The paper examined the strategic, operational, and financial performance of Commercial Bank of Ceylon Bangladesh Operations using its CAMEL-based performance record. For this study, financial data from the last seven years and organizational historical information, including updates to management structure, were collected. In addition, primary source of practical working experience and observance provided detailed operational information. Analysing the financial data through various key ratios and conducting CAMEL rating analysis has presented a thorough view from different sectors of the bank performance over time, which has ranged from outstanding to satisfactory in all sector parameters except for liability management. Comparison against local industry average has showed that the bank has been in quite a good position in local economy in terms of recent crises such as Non-Performing Loan (NPL) than banking industry. Despite the recommendation for an increase in manpower and promotion that will result in a decrease in liability, the paper also suggests an emphasis on reducing liability.

Keywords: Bank performance, rating, Commercial bank of Ceylon, CAMEL rating, and Financial analysis.

\section{INTRODUCTION:}

Banks and financial institutions are key elements of a sound financial system of the country (Ahmad et al., 2011; Anojan \& Nimalathasan, 2014). Bangladesh banking industry has been blooming since last three decades as more and more of the population (Pomi et al., 2021) are getting access to independent and personal banking with growing number of private, public and foreign commercial banks though it has been affected several sectors by COVID-19 (Ayittey et al., 2020, 2021; Chowdhury et al., 2021; Dhar et al., 2020). For the development of the economy of a developing country like Bangladesh, many severe social problems have been declined a lot in last few decades (Sarkar et al., 2018; Sarkar et al., 2021). Modern economic life depends on the banking system. People and manufacturers borrow money from banks to invest in their businesses. Banks, then, play a UniversePG I www.universepg.com vital role in generating new capital (or capital formation) in a country, which facilitates economic growth (Crowley et al., 2020; Dhar et al., 2014; 2017; 2018; 2019; 2020; 2021; Masruki et al., 2020; Saeed et al., 2017, 2018).

Digitalization and technological advancement have enabled banking to reach people of every level with different services such as microcredit and/or microfinance, agent banking, online or internet and mobile banking facilities. Regulated by the central bank of the country, Bangladesh Bank, there are currently 6 state-owned commercial banks (SOCBs), 3 specialized banks (SDBs), 42 (34 conventional and 8 Shariah-based) private commercial banks (PCBs) and 9 foreign commercial banks (FCBs) according to the Bangladesh Bank (2020). Foreign or international banks have played a major role in this great develop- 
ment with their various affordable and beneficiary products and offers to cater to different market segments (Chowdhury and Dhar, 2012). Especially, foreign banks contribute mostly tothe GDP of the country by making transactions of largest remittances from overseas. For the preparation of this study, CBC's annual reports for past several years have been collected. Information regarding products and services, major milestones and other operational activities has been collected and analyzed. Moreover, previous studies on the bank varying in subjects have been gathered and studied. The bank website and Bangladesh bank website also provided useful information. The detailed operational and functional analysis of a foreign bank such as $\mathrm{CBC}$ will provide an opportunity for coming students and researchers as a learning or information source. Further research may be based on this core concepts reviewed in this paper. This analysis mainly focused on the functional activities of the Bangladesh operations of this foreign bank. The SWOT analysis presented a clear view of bank position and banking industry.

The objective of this study is to explore and experience the inner workings and mechanisms of banking and analyze gathered information and learnings through established framework and methods. The aim is to study many aspects of banking such as management, marketing, financial and operational practices. Through this extensive study on different aspects, well understanding of foreign bank operation is expected to be achieved. It aspires to explore the bank's stance in the local industry and assess bank position through SWOT analysis.

\section{Background}

About 100 years ago, the Commercial Bank of Ceylon was founded. It was in that year when Eastern Bank (EBL) opened a branch in Sri Lanka's Chatham Street. The Chartered Bank bought the EBL share capital in 1957. In 1969, the Commercial Bank of Ceylon acquired $40 \%$ of EBL. After taking over the Mercantile bank in Galle, Jaffna, and Kandy in 1973, the Chartered bank took over the EBL in 1971. Following that, the foreign currency unit was established in 1979, and the Commercial Development Company (CDC) was incorporated to build the headquarters on 40 percent equity. Commercial House, No. 21, Bristol Street, became the headquarters of CBC after 4 years. Increasing share value and the introduction of innovative services helped the bank grow. A share of Chartered bank was sold to the bank in 1997. Bangla- desh operation was started in 2003 with the acquisition of two branches and two booths of Credit Agricole Indosuez, a French multinational bank. As a result, the Bangladesh remittance sector has been largely supported by CBC. CBC established its Bangladesh operation in 2003. Throughout its 17-year history in Bangladesh, $\mathrm{CBC}$ has formed an impressive customer base, achieved recognition, exhibited immaculate service, and set trends in smooth performance. A total of 11 branches were open in 2021 in the Dhaka, Chattogram, and Sylhet divisions of CBC. Moreover, the bank operates two offshore banking units (OBUs) in Dhaka (Gulshan) and Chattogram (CEPZ), as well as six SME centers. CBC emphasizes innovative product and service offerings, trend-setting performance, and customer satisfaction. Assure good corporate governance in order to maximize value for customers, employees, investors and the nation.

\section{Management Practices}

The bank plays an important role in practicing intellectual capital (Dhar 2019; 2020). CCBC has a sophisticated management structure. A Board of Directors comprised of 12 intellectual figures, currently headed by Mr. K Sripavan, is the independent governing body of the bank. Since its inception, Commercial Bank of Ceylon PLC has had many boards of directors.

In 2014, a new board was appointed. Then, between 2016 and 2018, more board members were appointed or changed. The new board of directors introduced many new and innovative strategies for the entire bank regardless of its branches or locations, which have contributed to improvements in the bank's performance. CBC offers extraordinary and totally customer-oriented products and services. Their marketing practices focuses primarily on establishing and maintaining customer relationship. It is first training that is taught to the newly acquired workers, interns or trainees, to establish smooth and long-lasting customer relations.

\section{Financial performance}

Commercial bank of Ceylon PLC has been steadily improving and expanding its territory from the beginning. Their unique services and revolutionary attitude retain its success which is adequately reflected in its financial performances. $\mathrm{CBC}$ follows regular banking accounting practices through Finance Department in Headquarters using reports from all branches, SMEs and OBUs. 


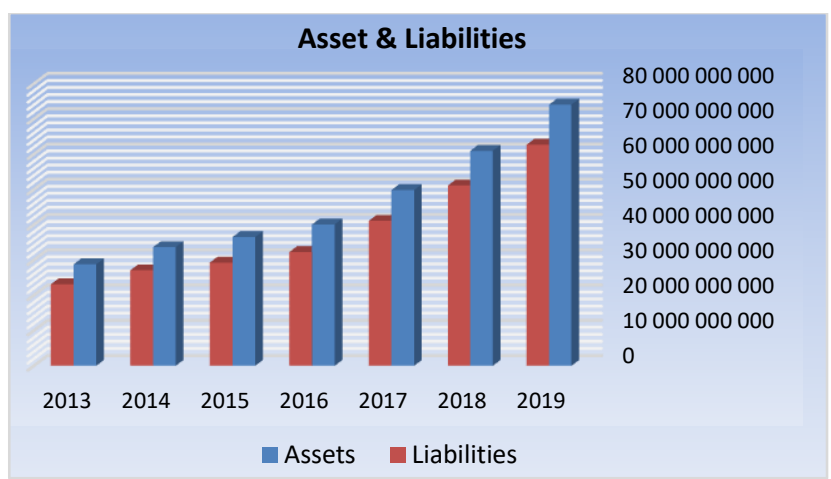

Fig. 1: Financial Position.

Using data from the past seven years, Fig. 1 describes that both assets and liabilities of the bank have steadily increased over time, which indicates that the bank is growing at a healthy rate for a foreign bank. In spite of this, asset levels are always higher than liabilities. Therefore, the bank maintains a healthy level of liquidity in case of a crisis.

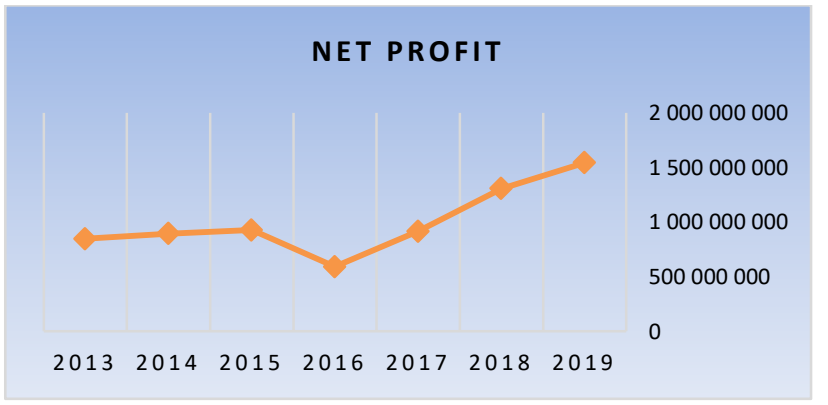

Fig. 2: Net Profit Movement.

Fig. 2 shows a trend of fluctuating net profit over time, with a drastic drop in net profit in 2016, but ever since the trend has been on a steady incline. A positive improvement in the financial performance of $\mathrm{CBC}$ is reflected in the bank's financial position and net profit movement.

Table 1: SWOT Analysis.

\section{Operations Management \& Information System Practices}

The main banking operations are maintained through an intra network system within the bank, which is directly regulated from its headquarters in mother country, Sri Lanka. The core banking software of CBC, International Comprehensive Banking System (ICBS) was introduced in 1993. By 1998, almost all branches were connected to the software. Currently, all banking activities are done using this software regardless of location, branch or any other criteria. Alliance Branch Teller or ABT is used for storing and reviewing sensitive information such as cash transactions, client signatures and other similar information. Only In-charges are allowed access to this software. Through this software, information can be viewed from any branch which makes it simple for any branch to serve all customers of the bank. Besides these main two software, other intranet services are used for internal connection and information flow. Flora network system is used for electronic fund transfer (EFT) and clearing cheques of other banks with the central bank.

\section{Competitive advantage of $\mathrm{CBC}$}

Banking industry is an expanding one in last few decades in Bangladesh. Foreign banks have become a crucial part of the banking industry with their stellar performance and strong management system. However, every position or situation has its both positive and negative sides. In order to assess CBC in terms of industry and competitiveness, a reputed framework, "SWOT" analysis has been conducted.

\begin{tabular}{|c|c|}
\hline Parameters & Focus Points \\
\hline $\begin{array}{c}\mathrm{S}= \\
\text { Strength }\end{array}$ & $\begin{array}{l}\text { - Reputation and Reliability as customer friendly } \\
\text { - Healthy performance growth } \\
\text { - Rising deposits and advances } \\
\text { - Amicable work environment } \\
\text { - Unique services and lasting client relations }\end{array}$ \\
\hline $\begin{array}{c}\mathrm{W}= \\
\text { Weakness }\end{array}$ & $\begin{array}{l}\text { - Bound to operate under strict regulation of BB as a foreign bank } \\
\text { - Insufficient publicity and marketing opportunities } \\
\text { - Lack of human resources } \\
\text { - Limited branches and ATM booths }\end{array}$ \\
\hline $\begin{array}{c}\mathrm{O}= \\
\text { Opportunity }\end{array}$ & $\begin{array}{l}\text { - Increasing publicity through inventive marketing strategies \& promotional activities through technology } \\
\text { - Enhancing online banking and other such remote banking facilities } \\
\text { - Automated enabling of core facilities such as e-statement } \\
\text { - Recruit more human resources }\end{array}$ \\
\hline $\begin{array}{c}\mathrm{T}= \\
\text { Threat }\end{array}$ & $\begin{array}{l}\text { - Competition against local banks with lower regulations } \\
\text { - Fluctuations in foreign exchange rate } \\
\text { - Government controlled policies }\end{array}$ \\
\hline
\end{tabular}


The purpose of this analysis in Table $\mathbf{1}$ is to inspect the overall operational activities and practices of the Commercial Bank of Ceylon PLC Bangladesh and assess its position as an organization and in its industry. In brief, CBC management is quite impressive with high authorities as well as authority group in every level, ensuring good corporate governance. They offer a variety of attractive and userfriendly services with customer-oriented attitude. It is a crucial factor in retaining long lasting client relationships. $\mathrm{CBC}$ has been performing quite well in terms of financial aspect and their inter-connected software services provide a seamless service for clients anywhere in the country. Despite such activities, CBC faces some weakness and threats in the industry and sole level. By identifying them accurately and taking appropriate measures, issues would be solved and CBC will be improving more in near future. Based on the above discussion and SWOT analysis, the following recommendations are presented. To begin with, the publicity and marketing should be increased using advancement of technologies. Keeping up with the unique trendsetter attitude, inventive bank marketing must be initiated. Then, more human resources must be hired in order to improve productivity and efficiency. Publicity of recruitment process among various universities through taking part in talent hunt and other similar programs can be great start for attracting newest talents. Next, increasing ATM booths across country is a key necessity for the convenience of customers. It is a crucial element in competing against the local banks. Gradually, branch numbers are to be increased as well in prime areas. Moreover, incentives to customers and employees are to be offered in order to compete successfully against local banks. Finally, distributing promotional stationaries are great ways to keep people aware of its services.

\section{CAMEL-based performance}

Chien and Danw, (2004) found that the majority of previous studies on company performance evaluation focused primarily on operational efficiency and effecttiveness, which are crucial to a company's survival. Efficient processes do not always lead to effective ones. Elizabeth and Ellot, (2004) found that the level of customer service quality correlated positively with all financial performance measures such as interest margin, return on assets, and capital adequacy. Therefore, customer-orientation is an integral part of ensuring effectiveness not only in banking, but also UniversePG I www.universepg.com in other businesses. CAMELS have proven to be an effective internal supervisory tool for evaluating a financial firm's soundness, especially effective in the banking industry, having been developed by the Uniform Financial Institutions Rating System (UFIRS). On the basis of the composite rating of individual banks' essential financial ratios, the system also indicates the bank's exposure to operational, financial and market risks. The CAMEL model is the most widely used to evaluate the financial performance of banks among academics, authorities, and regulators. Academics often use CAMELS frame-work to evaluate the internal (bank-specific) factors of a bank (Desta, 2016). Therefore, this study is prepared for the purpose of analyzing the overall performance of Commercial bank of Ceylon PLC through its major financial ratios. The objective is to interpret and understand the bank's financial stance in different aspects and categorize the ratios into major categories in order to assess overall performance through CAMEL rating system along with time-series analysis. This report will provide a one-stop view of performance on all sectors over time of the Commercial Bank of Ceylon PLC Bangladesh. Through this analytical approach, the bank management strategies and their consequences on performance will be assessed especially in case of credit management. This study will contribute to filling the gap of using CAMEL rating as an evaluation tool of a "singular" bank in Bangladesh. Through this study, the overall fitness of the CBC will be assessed and also the effectiveness of using CAMEL rating as assessment tool in this context will be analyzed (Mahmaud \& Rahman, 2020). Further research is encouraged to utilize the unique strategies of CBC in other financial organization for both academia and practical purpose. This research will open new opportunities for further research to apply this method for other CBC branches and operations in various countries \& other state-owned and commercial banks operating in Bangladesh.

\section{METHODOLOGY:}

Using data from the Commercial Bank of Ceylon PLC Bangladesh, a detailed time-series quantitative analysis has been conducted. Absar et al. (2021) gathered relevant information about the bank through both primary and secondary sources. The primary source of information came from daily interactions with customers, corporate clients, co-workers, and close exposure to regular bank dealings. The strategic, operational, and technical activities were monitored 
closely by the branch manager and other in-charges. Secondly, secondary information was gathered mainly from the commercial bank's website. Considering that annual reports are published by the bank as a whole, rather than by country, the comprehensive annual reports of those seven years were reviewed for information on operational and strategic developments, banking history, and a local and global perspective on the bank. The study has compiled and analyzed the financial statements of CBC PLC Bangladesh Operations for seven (7) consecutive years between 2013 and 2019. For secondary sources, previous studies and reports on $\mathrm{CBC}$ were collected. Banking ratios were used to analyze the financial information collected. CAMEL is a global rating system that categorizes and evaluates the ratios of banks. The link between the financial and strategic analysis was later examined.

\section{RESULTS AND ANALYSIS:}

\section{Risk-based Ratios}

In 2019, CBC had $32.60 \%$ total capital against its risk weighted assets which is a great CRAR. From 2013, CRAR has inclined with its highest in 2016 and then dropped for next two years (Fig. 3). It has started to increase again in 2019. Comparing to industry average, the bank is almost three times better performing than the rest of the industry.

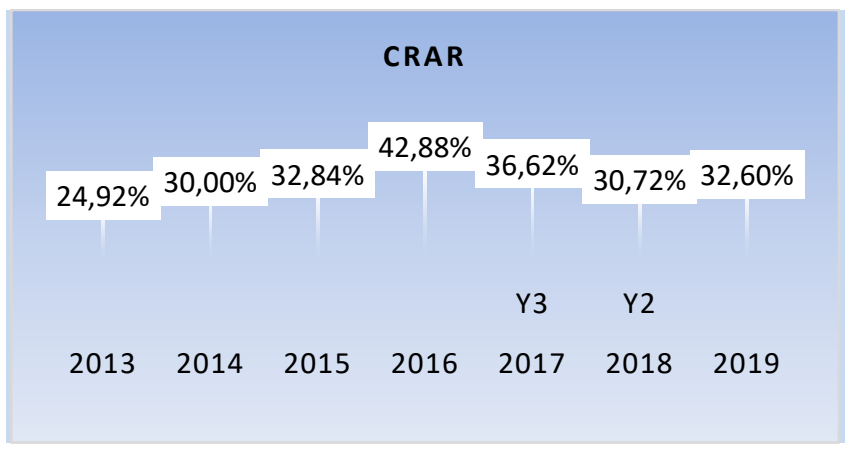

Fig. 3: CRAR Ratio.

Fig. 4 indicates that in 2019, CBC had $30.87 \%$ of core capital against its total risk weighted assets. Since 2013, CRAR has fluctuated with its peak in 2016 and then dropped for next two years. It started rising again in 2019. Comparing to industry average, the bank is over four times better performing than the rest of the industry.

\section{Efficiency}

In 2019, CBC incurred Tk. 32.17 operational cost to earn every Tk. 100 of operational income (Fig. 5). Since 2013, Cost-Income ratio has simultaneously fluctuated with its peak in 2016. For the past two years, it has remained almost stable with albeit slight decrease in last year.

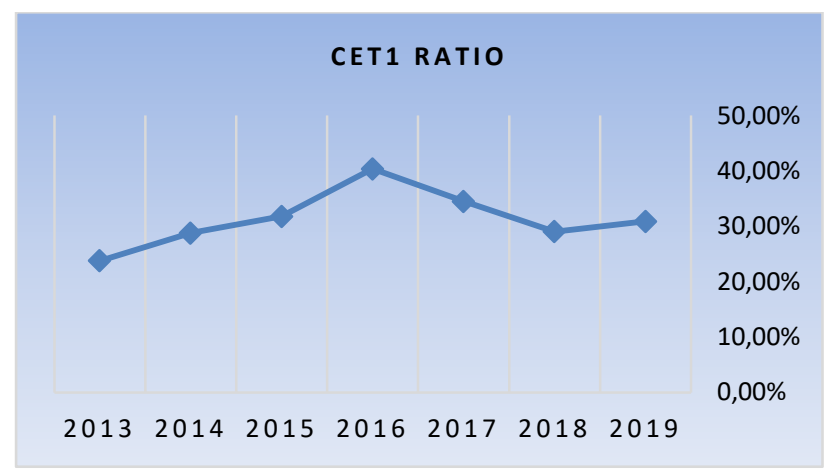

Fig. 4: Tier-1 Capital Ratio (CET1).

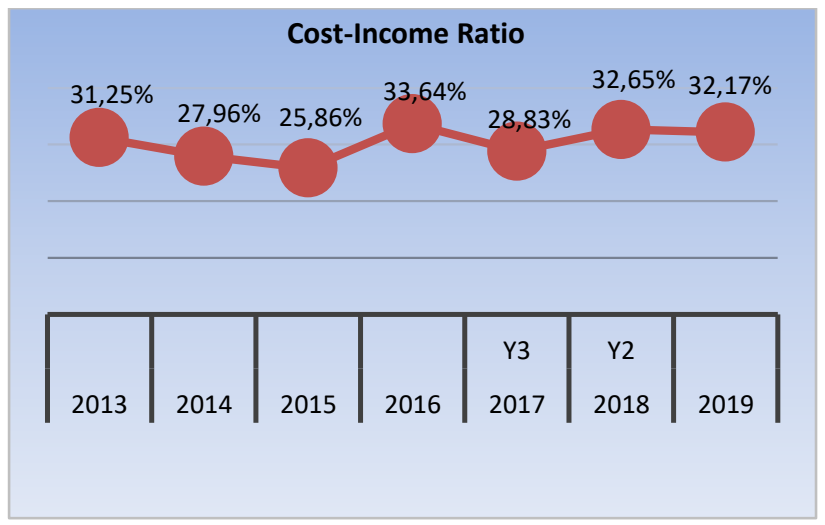

Fig. 5: Cost to Income Ratio.

\section{Debt Leverage}

In 2019, CBC owed Tk. 84.63 against every Tk.100 of assets owned and used Tk. 550.82 of its every Tk. 100 of its equity capital (Fig. 6). Over the past 7 years, the Debt to Assets ratio has remained somewhat stable. However, the Debt-to-Equity ratio has been inclining mostly on a steady rate for last seven years with a good increase in the latter years.

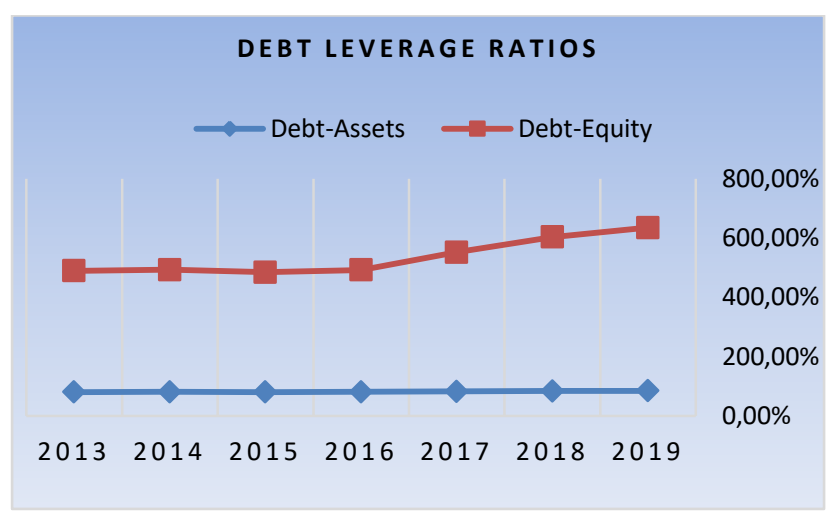

Fig. 6: Debt Leverage Ratios.

\section{Liquidity}

In $2019,138.17 \%$ of Liability to Deposit ratio means that the bank incurred Tk. 1.38 of liabilities against every taka of deposit collected (Fig. 7). Its highest peak in 2014 was followed closely by a drastic decline in 2015. Ever since the ratio has been rising on a 
steady inclining rate. Although in last year, it had dropped by almost 7 units.

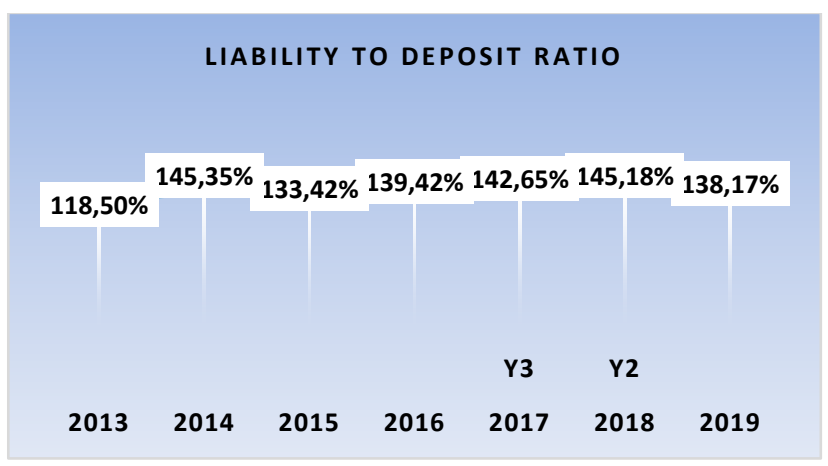

Fig. 7: Liability to Deposits Ratio.

In 2019, $105.79 \%$ of Loan to Deposit ratio means that the bank gave out Tk. 1.0579 of loans against every taka of deposit collected (Fig. 8). The ratio has been inclining since 2013 till 2017 and started to decline for past two years. In comparison with the industry benchmark, the bank has been operating in quite a risky method with high liquidity risk.

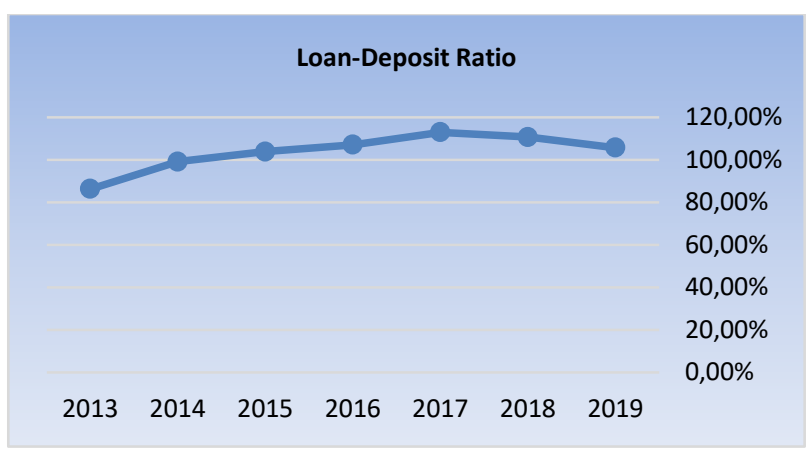

Fig. 8: Loan to Deposits Ratio.

In 2019, 0.14\% PLLs to Total Loans means that for every 100 loans given, 0.14 numbers of them were risky enough to be expected to turn out uncollectible (Fig. 9). The time series analysis projects that PLL for the bank has been fluctuating over the last seven years. With steady incline to 2016, it had started to drop ever since. Meaning the bank had started to become more conservative regarding giving risky loans.

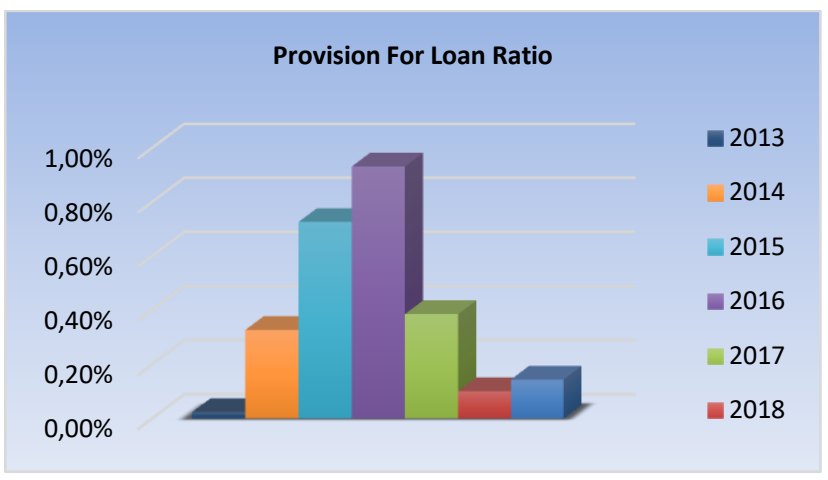

Fig. 9: Provisions for Loans Ratio.
In 2019, 0.75\% NPLs to Total Loans means that for every 100 loans given, 0.75 numbers of them were uncollectible (Fig. 10). According to the time-series analysis, NPLs had been increasing quite alarmingly till 2015. But from 2016, the NPLs have been falling in quite an impressive rate. In contrast with the industry rate, the bank has been doing great over the years.

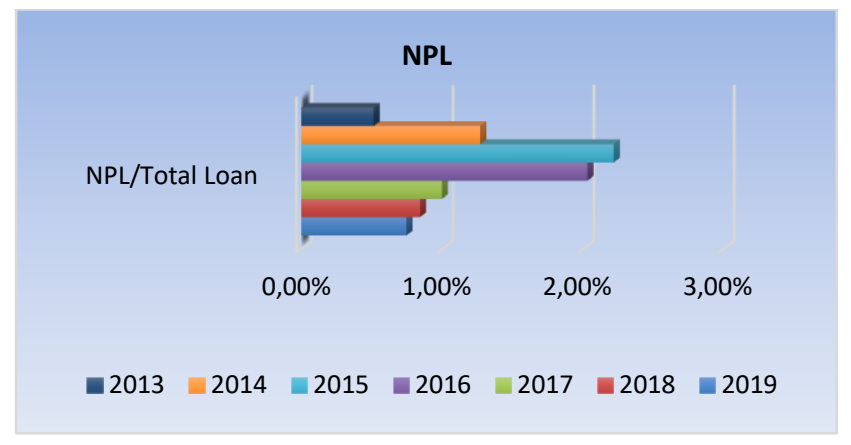

Fig. 10: Non-Performing Loan Ratio.

\section{Return-based Ratios}

In 2019, 2.61\% NIM means that every unit of their asset has earned Tk. 0.0261 of interest income (Fig. 11). Over the last seven years, NIM for the bank has been fluctuating at the almost same level.

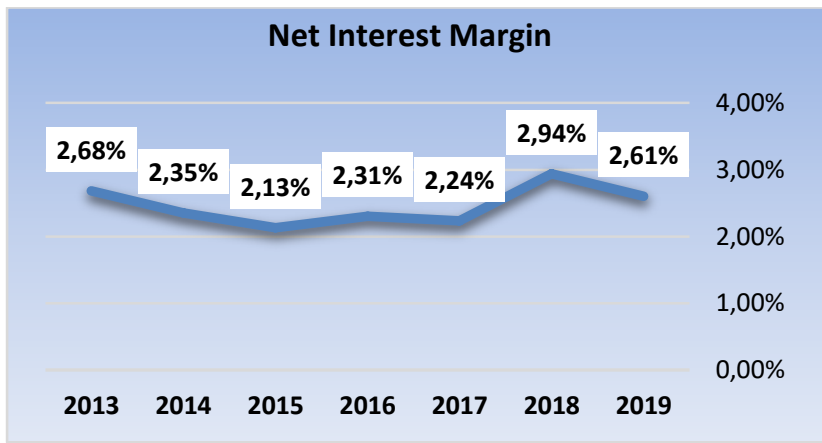

Fig. 11: Net Interest Margin.

\section{Earning Capacity}

In $2019,2.08 \%$ of ROA means that every unit of their assets has earned Tk.0.0208 of income. 13.55\% ROE means that every unit of their equity has earned 0.1355 taka of income (Fig. 12). From the timeseries analysis, although ROA has been stable over the years with slight fluctuations, ROE has dropped dramatically in 2016. However, it had almost recovered as of 2019. CBC has been operating much better at both its ROA and ROE as compared to the industry average of these ratios.

\section{CAMEL Rating Analysis}

The major financial ratios of the $\mathrm{CBC}$ as derived in the previous section have been assessed using an international performance rating system for banks namely "CAMEL Rating System". 


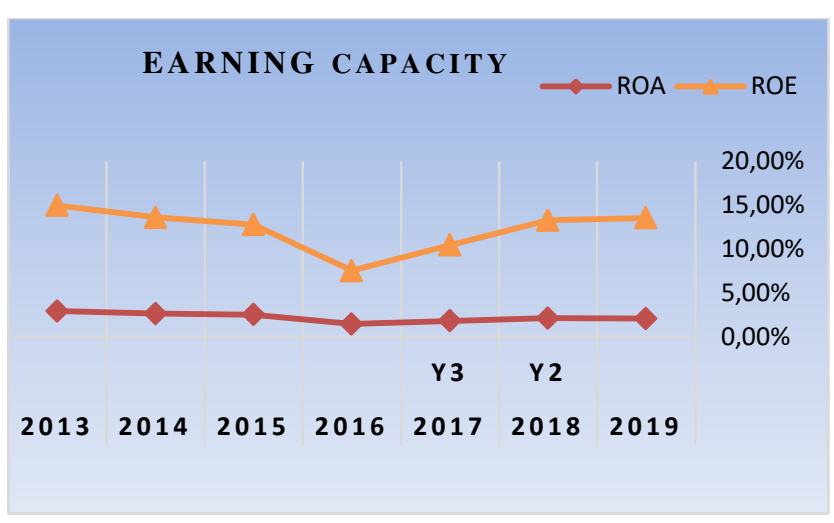

Fig. 12: Earning Capacity.

Selected appropriate ratios were divided into five categories to best assess various aspects of the bank for each year. After that, average ratings of the calculated seven-year data in different categories were considered and analyzed. According to Desta, (2016) "CAMELS rating is a financial performance evaluation system often applied to the banking industry,

\begin{tabular}{|c|c|c|c|c|c|c|}
\hline \multirow{2}{*}{\multicolumn{2}{|c|}{ CAMEL Component }} & \multicolumn{5}{|c|}{ Ratio's Rating } \\
\hline & & 1 & 2 & 3 & 4 & 5 \\
\hline \multicolumn{2}{|c|}{ Capital Adequacy Ratio } & $>15 \%$ & $12-14.99 \%$ & $8-11.99 \%$ & 7-7.99\% & $<6.99 \%$ \\
\hline \multicolumn{2}{|c|}{ Asset Quality Ratio (NPLSTLL) } & $<1.25 \%$ & $<2.5-1.26 \%$ & $<3.5-2.6 \%$ & $\langle 5.5-3.6 \%$ & $>5.6 \%$ \\
\hline \multicolumn{2}{|c|}{ Management Effficiency (Cost//ncome) } & $<25 \%$ & $30.26 \%$ & $38.31 \%$ & $45 \cdot 39 \%$ & $>46 \%$ \\
\hline \multirow[t]{2}{*}{ Earnings Ability } & (ROA) & $>1.5 \%$ & $1.25 \cdot 1.5 \%$ & $1.01 \cdot 1.25 \%$ & $0.75 \cdot 1.00 \%$ & $<0.75 \%$ \\
\hline & (ROE) & $>22 \%$ & $17 \cdot 21.99 \%$ & $10 \cdot 16.99 \%$ & $7 \cdot 9.99 \%$ & $<6.99 \%$ \\
\hline \multicolumn{2}{|l|}{ Liquidity (TLTTD) } & $<55 \%$ & $62.56 \%$ & $68.63 \%$ & $80 \cdot 69 \%$ & $>81 \%$ \\
\hline
\end{tabular}

Source: Babar and Zeb, (2011) and Rozzani and Rahman, (2013), as cited by Desta, (2016) which is originally developed by the Uniform Financial Institutions Rating System (UFIRS)." The six components stand as acronyms for the name. The parameters are as follows, $\mathrm{C}=\mathrm{Capital}$ Adequacy, $\mathrm{A}=$ Asset Quality, M= Management Efficiency, E= Earning Capacity, $\mathrm{L}=$ Liquidity Management and $\mathrm{S}=$ Sensitivity to Market. The sixth parameter is excluded in this study because of lack of information. The selected relevant ratios are rated according to the following table from a study on African banks by Desta, (2016).

After rating each individual category, an average rating has been derived over time and the rating has been interpreted to provide the final comprehensive report on the organization, as per the following table taken from the above-mentioned study by Desta, (2016).

\begin{tabular}{|c|c|l|l|}
\hline Rating & $\begin{array}{c}\text { Rating } \\
\text { Range }\end{array}$ & \multicolumn{1}{|c|}{ Rating Analysis } & \multicolumn{1}{|c|}{ Interpretation } \\
\hline 1 & $1.0-1.4$ & Strong (or outstanding) & The bank is basically good in every aspect. \\
\hline 2 & $1.6-2.4$ & Satisfactory (or superior) & $\begin{array}{l}\text { The bank is primarily good, but has several } \\
\text { identified weaknesses. }\end{array}$ \\
\hline 3 & $2.6-3.4$ & $\begin{array}{l}\text { Fair (or average), with some } \\
\text { categories to be watched }\end{array}$ & $\begin{array}{l}\text { The bank have financial, operational, or } \\
\text { compliance weaknesses that would give } \\
\text { reasons for supervisory concern. }\end{array}$ \\
\hline 4 & $3.6-4.4$ & $\begin{array}{l}\text { Marginal (or under perform), } \\
\text { with some risk of failure }\end{array}$ & $\begin{array}{l}\text { The bank has serious financial weaknesses } \\
\text { that could damage future capability to ensure } \\
\text { normal growth and development. }\end{array}$ \\
\hline 5 & $4.6-5.0$ & $\begin{array}{l}\text { Unsatisfactory (or doubtful), } \\
\text { with a high degree of failure }\end{array}$ & $\begin{array}{l}\text { The bank has critical financial weaknesses } \\
\text { that will give a probability of failure to be } \\
\text { extremely high in the near future. }\end{array}$ \\
\hline
\end{tabular}

Source: Babar and Zeb, (2011) and Rozzani and Rahman, (2013), as cited by Desta, (2016).

Table 2: CAMEL Ratings Result.

\begin{tabular}{|c|c|c|c|c|c|c|c|c|c|c|}
\hline $\begin{array}{c}\text { CAMEL } \\
\text { Parameter }\end{array}$ & Ratios & 2019 & 2018 & 2017 & 2016 & 2015 & 2014 & 2013 & $\begin{array}{c}\text { Average } \\
\text { Rating }\end{array}$ & Comment \\
\hline \multirow{2}{*}{$\begin{array}{c}\text { Capital } \\
\text { Adequacy }\end{array}$} & CRAR & $32.60 \%$ & $30.72 \%$ & $36.62 \%$ & $42.88 \%$ & $32.84 \%$ & $30.00 \%$ & $24.92 \%$ & \multirow[t]{2}{*}{1} & \multirow{2}{*}{$\begin{array}{l}\text { Strong and } \\
\text { Outstanding }\end{array}$} \\
\hline & Rating - CAR & 1 & 1 & 1 & 1 & 1 & 1 & 1 & & \\
\hline \multirow[t]{2}{*}{ Asset Quality } & NPL/Total Loan & $0.75 \%$ & $0.84 \%$ & $1.00 \%$ & $2.03 \%$ & $2.22 \%$ & $1.27 \%$ & $0.51 \%$ & \multirow[t]{2}{*}{1} & \multirow{2}{*}{$\begin{array}{l}\text { Strong and } \\
\text { Outstanding }\end{array}$} \\
\hline & Rating & 1 & 1 & 1 & 2 & 2 & 2 & 1 & & \\
\hline \multirow[t]{2}{*}{$\begin{array}{l}\text { Management } \\
\text { Efficiency }\end{array}$} & $\begin{array}{l}\text { Total Cost / } \\
\text { Total Income }\end{array}$ & $32.17 \%$ & $32.65 \%$ & $28.83 \%$ & $33.64 \%$ & $25.86 \%$ & $27.96 \%$ & $31.25 \%$ & \multirow[t]{2}{*}{2} & \multirow[t]{2}{*}{ Satisfactory } \\
\hline & Rating & 3 & 3 & 2 & 3 & 1 & 2 & 2 & & \\
\hline \multirow{4}{*}{$\begin{array}{c}\text { Earning } \\
\text { Capacity }\end{array}$} & ROA & $2.08 \%$ & $2.14 \%$ & $1.83 \%$ & $1.47 \%$ & $2.54 \%$ & $2.66 \%$ & $2.94 \%$ & \multirow[t]{2}{*}{1} & \multirow{2}{*}{$\begin{array}{l}\text { Strong and } \\
\text { Outstanding }\end{array}$} \\
\hline & Rating - ROA & 1 & 1 & 1 & 2 & 1 & 1 & 1 & & \\
\hline & $\mathrm{ROE}$ & $13.55 \%$ & $13.29 \%$ & $10.46 \%$ & $7.54 \%$ & $12.79 \%$ & $13.62 \%$ & $14.97 \%$ & \multirow[t]{2}{*}{3} & \multirow{2}{*}{$\begin{array}{c}\text { Fair or } \\
\text { Average }\end{array}$} \\
\hline & Rating- ROE & 3 & 3 & 3 & 4 & 3 & 3 & 3 & & \\
\hline \multirow[t]{2}{*}{$\begin{array}{c}\text { Liquidity } \\
\text { Management }\end{array}$} & $\begin{array}{l}\text { Total Liabilities } \\
\text { / Total Deposit }\end{array}$ & $138.17 \%$ & $145.18 \%$ & $142.65 \%$ & $139.42 \%$ & $133.42 \%$ & $145.35 \%$ & $118.50 \%$ & \multirow[t]{2}{*}{5} & \multirow{2}{*}{$\begin{array}{l}\text { Unsatis- } \\
\text { factory or } \\
\text { Doubtful }\end{array}$} \\
\hline & Rating & 5 & 5 & 5 & 5 & 5 & 5 & 5 & & \\
\hline
\end{tabular}


The above data in Table 2 shows that $\mathrm{CBC}$ has been operating quite successfully as a bank in almost all aspects. The CAMEL rating analysis reveals that the bank is performing strong and outstanding in three of the five categories such as capital adequacy, asset management and ROA of earning capacity. CBC's performance in management efficiency and ROE of earning capacity has been satisfactory and fair respectively. The only lacking of the bank seems to be in liquidity management aspect. Their performance in that department is unsatisfactory or doubtful because of very high usage of liquid assets.

\section{CONCLUSION:}

The study examined the performance of the Commercial Bank of Ceylon PLC Bangladesh through a global rating method over the past several years. CAMEL analysis and financial ratios show that Commercial Bank of Ceylon PLC is a sound bank from almost all perspectives. In an era when the banking industry of this country is suffering immensely, scoring outstanding in three out of five categories is much impressive. CBC appears to have been largely untouched by the main crisis facing the banking industry, the rise of non-performing loans. This actually increased in 2015. However, since 2016, NPLs have dropped dramatically. In addition, most of the bank's financial ratios started improving at that time. CBC PLC Bangladesh turned a corner in 2016 as a result of the above analysis and study of annual reports. The Bangladesh operations of CBC PLC changed their operation strategies this year, becoming a bit more conservative when choosing customers or disbursing loans, as well as raising equity capital. However, there was no major event of significance in 2016. From 2014 to 2018, the bank's management has been slowly changing. More board members have been appointed, and the bank's financial performance has improved. It is clear that the new panel of board of directors has had a notable effect on the performance of the bank by implementing new strategies. Non-performing loans are only $0.75 \%$ in 2019 , which is significantly lower than the industry average of $3.70 \%$. A close examination reveals that by screening lending customers carefully and establishing reliable customer relationships, non-performing loans can be virtually eliminated. Liquidity management is the only area of weakness. The bank gives out more liabilities than they collect deposits, despite sound asset and capital management and conservative loan giving. In other words, in the event of a liquidity UniversePG I www.universepg.com crisis, the bank would not be able to pay off its liabilities with liquid deposits.

\section{Recommendation}

CBC is quite impressive and successful in its operative ways as a foreign bank in Bangladesh. Naturally the main suggestion upon inspecting the above analysis would be to improve their weak link, liquidity management. Increasing their deposit collection is highly recommended. Alternatively, working on decreasing liabilities can also be a focus to eradicate this impending crisis. Decreasing operational costs and increasing operational and off-balance sheet incomes is to be recommended to enhance the solvency of the bank. $\mathrm{CBC}$ is quite impressive and successful in its operative ways as a foreign bank in Bangladesh. Naturally the main suggestion upon inspecting the above analysis would be to improve their weak link, liquidity management. Increasing their deposit collection is highly recommended. Alternatively, working on decreasing liabilities can also be a focus to eradicate this impending crisis. Decreasing operational costs and increasing operational and off-balance sheet incomes is to be recommended to enhance the solvency of the bank.

\section{ACKNOWLEDGEMENT:}

I would like to express my gratitude toward Professor Dr. Sang H. Lee and Professor Mohammad Mujibul Haque of BRAC Business School. Moreover, I offer my heartiest thanks to all the officials of Commercial Bank of Ceylon PLC.

\section{CONFLICTS OF INTEREST:}

The authors have no conflicts of interest in publishing this research study.

\section{REFERENCES:}

1) Absar, M. M. N., Dhar, B. K., \& Emran, M. (2021). Sustainability disclosures in emerging economies: Evidence from human capital disclosures on listed banks' websites in Bangladesh. Business and Society Review, 126(3), 363-378. https://doi.org/10.1111/basr.12242

2) Anojan, V., \& Nimalathasan, B. (2014). A Comparative Study of Financial Performance of State and Private Sector Commercial Banks in SriLanka: An Application of CAMEL Rating System. Faculty of Management Studies and Commerce, University of Jaffna, Sri Lanka.

3) Ayittey, F.K., Dhar, B.K. and Tettey, E.L. (2021), Epidemiology, Clinical Characteristics, and Treatment of SARS-CoV-2 Infection in 
Children: A Narrative Review. International J. of Clinical Practice. Manuscript e15012. https://doi.org/10.1111/ijcp.15012

4) Ayittey, F. K., Dhar, B. K., and Chiwero, N. B. (2020). Gendered burdens and impacts of SARS-CoV-2: a review. Health Care for Women International, 41(11-12), 1210-1225. https://doi.org/10.1080/07399332.2020.1809664

5) Bangladesh Bank. (2020). Financial SystemsBanks \& FIs. Retrieved from https://www.bb.org.bd/fnansys/bankfi.php

6) Chien, T., \& Danw, S. Z. (2004). Performance Measurement of Taiwan Commercial Banks. International $J$. of Productivity and Performance Management, 53(5), 425-434.

7) Chowdhury, E. K., Khan, I. I., \& Dhar, B. K. (2021). Catastrophic impact of Covid-19 on the global stock markets and economic activities. Business and Society Review, 1-16. https://doi.org/10.1111/basr.12219

8) Chowdhury, R. and Dhar, B. K. (2012). The Perspective of Loan Default Problems of the Commercial Banking Sector of Bangladesh: A Closer looks into the Key Contributory Factors. University of Science and Technology Annual (USTA), 18(1), 71-87.

9) Commercial Bank of Ceylon PLC Bangladesh. (2013). Annual Report 2019. Retrieved from https://www.combank.net.bd/images/2020/Comm ercial_Bank_Annual-Report_2019-CSE-Version. pdf

10) Commercial Bank of Ceylon PLC Bangladesh. (2013). Auditor's Report and Financial Statements 2013. Retrieved from https://www.combank.net.bd/images/pdffiles/CBC BD/WEB_CBC_BGD_2013.pdf

11) Commercial Bank of Ceylon PLC Bangladesh. (2014). Auditor's Report and Financial Statements 2014. Retrieved from https://www.combank.net.bd/images/pdffiles/CBC _BD/Financial-Statements---2014_0.pdf

12) Commercial Bank of Ceylon PLC Bangladesh. (2015). Auditor's Report and Financial Statements 2015. Retrieved from https://www.combank.net.bd/images/pdffiles/CBC _BD/Financial-Statement-for-the-Year-2015.pdf

13) Commercial Bank of Ceylon PLC Bangladesh. (2016). Auditor's Report and Financial Statements 2016. Retrieved from https://www.combank.net.bd/images/pdffiles/CBC _BD/FS_WEB.pdf
14) Commercial Bank of Ceylon PLC Bangladesh. (2017). Auditor's Report and Financial Statements 2017. Retrieved from -

https://www.combank.net.bd/images/2018/Disclos ure/Financial_Statement_2017_0.pdf

15) Commercial Bank of Ceylon PLC Bangladesh. (2018). Auditor's Report and Financial Statements 2018. Retrieved from -

https://www.combank.net.bd/images/2019/AFS/Fi nancial-Statement---2018.pdf

16) Commercial Bank of Ceylon PLC Bangladesh. (2019). Auditor's Report and Financial Statements 2019. Retrieved from -

https://www.combank.net.bd/images/2020/Financi al_Statement_2019_CBCPLC.pdf

17) Commercial Bank of Ceylon PLC Bangladesh. (n.d.). Retrieved from https://www.combank.net.bd/en/

18) Crowley, S. S., Rahat, A. W. K., Dhar, B. K. (2020). Impact of Accountability in Social Media on Customer Satisfaction in Online Retail Businesses of Bangladesh. Advances in Management. 13 (4), 24-29.

https://doi.org/10.6084/m9.figshare.16821448.v1

19) Desta, T. S. (2016). Financial performance of "The best African banks": A comparative analysis through CAMEL rating. Journal of Accounting and Management, 6(1), 1-20.

https://hrcak.srce.hr/162948

20) Dhar, B. K., Ayittey, F. K., \& Sarkar, S. M. (2020). Impact of COVID-19 on Psychology among the University Students. Global Challenges, 4(11), 2000038.

https://doi.org/10.1002/gch2.202000038

21) Dhar, B. K., Harymawan, I., \& Sarkar, S. M. (2021). Impact of corporate social responsibility on financial expert CEOs' turnover in heavily polluting companies in Bangladesh. Corporate Social Respons. and Environ. Management. https://doi.org/10.13140/RG.2.2.17829.83684

22) Dhar, B. K., Masruki, R., \& Absar, M. M. N. (2017). Impact of Islamic human resource practices on organizational performance through organizational commitment in the banking sector of Bangladesh. In 7th Islamic Economic System Conference (iEcons), Muscat, Oman.

23) Dhar, B. K., Sarkar, S. M., \& Ayittey, F. K. (2021). Impact of social responsibility disclosure between implementation of green accounting and sustainable development: A study on heavily polluting companies in Bangladesh. 
Corporate Social Responsibility and Environmental Management. https://doi.org/10.1002/csr.2174

24) Dhar, B. K, Mahazan, M. and Farid, A. S. (2020). Overcoming Unemployment through Vocational Education: The Role of Counsellors in China. Advances in Manag., 13(3), 22-25. https://doi.org/10.6084/m9.figshare.16760509.v1

25) Dhar, B. K. (2019). The Impact of Intellectual Capital on Organizational Performance in the Banking Sector of Bangladesh (Doctoral dissertation, Universiti Sains Malaysia). https://doi.org/10.13140/RG.2.2.26809.19047

26) Dhar, B. K. (2020). Impact of COVID-19 on Chinese Economy. Economic Affairs, 9(3/4), 23-26. https://doi.org/10.6084/m9.figshare.16761442.v1

27) Dhar, B.K. and Mutalib, M. (2020). Leadership of Xi Jinping behind Unstoppable Sustainable Economic Growth of China. International Journal of Organizational Leadership, 9, 39-47. https://doi.org/10.33844/ijol.2020.60489

28) Dhar, B.K., Hoque, M.M. and Chowdhury, R. (2014). Prospects and Problems of Green Marketing in Bangladesh. University of Science and Technology Annual, 20(6), 45-53. https://doi.org/10.6084/m9.figshare.16761898.v1

29) Dhar, B. K., Mahazan, M., \& Sobhani, F. A. (2020). Overcoming Unemployment through Vocational Education: The Role of Counsellors in China. Advances in Manag., 13(3), 22-25. https://doi.org/10.6084/m9.figshare.16760509.v1

30) Dhar, B. K., Masruki, R., and Absar, M. M. N. (2018). Mediating Effect of Organizational Commitment between Islamic Human Resource Practices and Organizational Performance among Islamic Banks of Bangladesh. The J. of Muamalat and Islamic Finance Research. 15(2), 5465. https://doi.org/10.33102/jmifr.v15i2.177

31) Dhar, B.K., Mutalib, M. and Sobhani, F.A. (2017). Investigating the Impact of Human Resource Accounting Practice on Organizational Performance. In International Islamic Social Economic Conference, Universiti Sains Islam Malaysia, Malaysia.

32) Dhar, B. K., Mutalib, M. and Sobhani, F.A. (2019). Determining effective dimensions of intellectual capital. Australian Academy of Accounting and Finance Review, 4(4), 166-185. https://doi.org/10.6084/m9.figshare.16762057.v1
33) Dhar, B. K., Mutalib, M. and Sobhani, F. A. (2019). Effect of Innovation Capability on Human Capital and Organizational Performance. International J. of Advanced Science and Technology, 29(4), $7074-7087$.

https://doi.org/10.6084/m9.figshare.16762171.v1

34) Elizabeth, D., Greg, \& Ellot, (2004). Efficiency Customer Service and Financial Performance among Australian Financial Institutions. International J. of Bank Marketing, 22(5), 319-342. https://doi.org/10.1108/02652320410549647

35) Mahmud A and Rahman MH. (2020). Evaluation and comparison of financial soundness of Islamic and conventional private commercial banks in Bangladesh: a CAMEL approach, $\mathrm{Can}$. J. Bus. Inf. Stud., 2(6), 129-140. https://doi.org/10.34104/cjbis.020.01290140

36) Masruki, R., Khairulannuar, H. H., \& Dhar, B. K. (2020). Shariah Accountability Practice of Malaysian Foreign-Owned Islamic Banks and Bahrain Islamic Banks. International J. of Advanced Sci. and Technol., 29(4), 5768- 5782. http://sersc.org/journals/index.php/IJAST/article/v iew/27085

37) Masruki, R., Samsudin, N. S., \& Dhar, B. K. (2020). Shariah accountability practices of Islamic banks in Malaysia. International Journal of Advanced Science and Technology, 29(4), 6954. http://sersc.org/journals/index.php/IJAST/article/v iew/28097

38) Pomi, S. S., Sarkar, S. M., \& Dhar, B. K. (2021). Human or physical capital, which influences sustainable economic growth most? A study on Bangladesh. Canadian J. of Business and Information Studies, 3(5), 101-108. https://doi.org/10.34104/cjbis.021.01010108

39) Saeed, M. A. Y., Bekhet, H. A., \& Dhar, B. K. (2017). Constructing model to explore the influence of marketing audit on organizational performance- An innovative arena of marketing. Australian J. of Basic and Applied Sciences, 11(15), 83-90.

http://www.ajbasweb.com/old/ajbas/2017/Decemb er-supp1/83-90(12).pdf

40) Saeed, M. A. Y., Bekhet, H. A., \& Dhar, B. K. (2018). Influence of marketing strategy audit on organizational performance through innovation capability in the corporate sector of Muscat, Oman. International Journal of Business Management, 1(2), 40-55. https://doi.org/10.6084/m9.figshare.16821457 
41) Sarkar, S. M., Dhar, B. K. \& Rouhoma, H. M. (2018). A Cross Sectional Analysis of Socioeconomic Determinants on Infant Mortality in South Asian Region. International Journal of Business Society, 2(2), 1-6.

https://doi.org/10.6084/m9.figshare.16762570.v1
42) Sarkar, S. M., Dhar, B. K., Gazi, M. A. I. (2021). Psychological Adjustment and Guidance for Ageing Urban Women, Ageing International. Pp. 1-9. https://doi.org/10.1007/s12126-021-09467-1

\section{Appendix}

\begin{tabular}{|c|c|c|c|c|c|c|c|c|}
\hline \multicolumn{7}{|c|}{ Financial Ratios } \\
\hline & Formula & $\mathbf{2 0 1 9}$ & $\mathbf{2 0 1 8}$ & $\mathbf{2 0 1 7}$ & $\mathbf{2 0 1 6}$ & $\mathbf{2 0 1 5}$ & $\mathbf{2 0 1 4}$ & $\mathbf{2 0 1 3}$ \\
\hline CRAR & $\begin{array}{c}\text { (Tier1 Capital + Tier 2 } \\
\text { Capital/Total Risk-weighted assets }\end{array}$ & $32.60 \%$ & $30.72 \%$ & $36.62 \%$ & $42.88 \%$ & $32.84 \%$ & $30.00 \%$ & $24.92 \%$ \\
\hline CET1 Ratio & $\begin{array}{c}\text { Tier1 Capital/Total Risk-weighted } \\
\text { assets }\end{array}$ & $30.87 \%$ & $29.03 \%$ & $34.49 \%$ & $40.36 \%$ & $31.76 \%$ & $28.78 \%$ & $23.76 \%$ \\
\hline Cost-Income Ratio & Operating Cost/Operating Income & $32.17 \%$ & $32.65 \%$ & $28.83 \%$ & $33.64 \%$ & $25.86 \%$ & $27.96 \%$ & $31.25 \%$ \\
\hline PLL Ratio & Provision for Loan/ Total Loans & $0.14 \%$ & $0.10 \%$ & $0.38 \%$ & $0.93 \%$ & $0.73 \%$ & $0.33 \%$ & $0.02 \%$ \\
\hline $\begin{array}{c}\text { NPL-Total Loans } \\
\text { Ratio }\end{array}$ & $\begin{array}{c}\text { Non-performing Loans/Total Loans } \\
\text { Debt-Assets }\end{array}$ & $0.75 \%$ & $0.84 \%$ & $1.00 \%$ & $2.03 \%$ & $2.22 \%$ & $1.27 \%$ & $0.51 \%$ \\
\hline Debt-Equity & Total Debts/Total Assets & $84.63 \%$ & $83.88 \%$ & $82.46 \%$ & $80.47 \%$ & $80.17 \%$ & $80.50 \%$ & $80.36 \%$ \\
\hline Net Interest Margin & Net Interest Income/Total Assets & $2.61 \%$ & $2.94 \%$ & $2.24 \%$ & $2.31 \%$ & $2.13 \%$ & $2.35 \%$ & $2.68 \%$ \\
\hline ROA & Net Income After Tax/ Total Assets & $2.08 \%$ & $2.14 \%$ & $1.83 \%$ & $1.47 \%$ & $2.54 \%$ & $2.66 \%$ & $2.94 \%$ \\
\hline ROE & Net Income After Tax/ Total Equity & $13.55 \%$ & $13.29 \%$ & $10.46 \%$ & $7.54 \%$ & $12.79 \%$ & $13.62 \%$ & $14.97 \%$ \\
\hline EPS & Net Income After Tax/Share & $32.61 \%$ & $27.28 \%$ & $18.89 \%$ & $13.00 \%$ & $20.83 \%$ & $20.07 \%$ & $18.60 \%$ \\
\hline $\begin{array}{c}\text { Outstanding } \\
\text { Liability-Deposit } \\
\text { Ratio }\end{array}$ & Total Liabilities/Total Deposits & $138.17 \%$ & $145.18 \%$ & $142.65 \%$ & $139.42 \%$ & $133.42 \%$ & $145.35 \%$ & $118.50 \%$ \\
\hline Loan-Deposit Ratio & Total Loans/Total Deposits & $105.79 \%$ & $110.73 \%$ & $113.02 \%$ & $107.12 \%$ & $103.85 \%$ & $99.21 \%$ & $86.33 \%$ \\
\hline
\end{tabular}

Citation: Crowley SS, Sikder MR, and Dhar A. (2022). CAMEL- based performance of a foreign bank in Bangladesh: a study on commercial bank of Ceylon, Int. J. Manag. Account. 4(1), 01-11. https://doi.org/10.34104/ijma.022.01011@ @ @ 